\title{
Redefining terminology for medical eponyms
}

\author{
Steven Howard Yale ${ }^{1}$, Halil Tekiner ${ }^{2}$, Eileen Scott Yale ${ }^{3}$ \\ ${ }^{1}$ University of Central Florida College of Medicine, Department of Internal Medicine, United States \\ ${ }^{2}$ Department of the History of Medicine and Ethics, Erciyes University School of Medicine, Turkey \\ ${ }^{3}$ University of Florida, Division of General Internal Medicine, United States
}

\section{Dear Editor,}

We read with interest Nieradko-Iwanicka's article on "National eponyms in medicine" and herein contribute further to the discussion [1]. Medical eponyms remain a contentious issue as there are those who promote and others who oppose their use. We propose a framework and contextual method of how to approach medical eponyms. This involves appropriately defining the term, understanding factors which support or reject their use, and recognizing potential application of their use in diagnosis and teaching pathophysiology, structural, and functional aspects of disease.

Nieradko-Iwanicka defined an eponym as "a person, place or thing after whom or after which something is named" [1]. We contend that this definition is too broad, overlaps with, and is often used in the same context as a medical eponym; the term we propose is more restrictive in definition. In developing a revised definition of a medical eponym we adopted and applied concepts based on nomenclature guidelines previously proposed for future naming patterns for malformations at the National Institutes of Health ( $\mathrm{NIH})$ [2] and best practice standards for naming new human infectious diseases that impact global health by the World Health Organization (WHO) [3, 4]. Key highlights in the NIH statement included that current designations should remain unless there is compelling reason for change, use of a single name, avoiding possessive name use, and names that may draw "unpleasant connotation for the family and/ or affected individuals" [2]. The WHO more specifically addressed the latter concern in that the name chosen should not include reference to a "cultural, social, national, regional, professional or ethnic group" [4]. Thus, names of people, geographic locations, cultural population, with industry or occupational reference or that may cause fear or harm should not be used in order to avoid potentially stigmatizing "nations, economies, people, and animals" [4, 5].

Based on these principles, we propose that a medical eponym in clinical medicine is an honorific term bestowed to an individual(s) who identified or discovered a disease, sign, symptom, syndrome, test, finding, anatomical part, or designed a device, procedure, view, treatment, classification, prediction rule, principle, or algorithm. Thus medical eponyms include those aspects which involve patient care or applications of care. Since the term connotes respect and honors a person's accomplishment(s), any name proven without a reasonable doubt to be associated with racial, fascist, or anti-Semitic beliefs or behaviors or other inhuman atrocities against people or society (e.g. rape, homicide, or genocide) should be expunged from literature and usage [6]. Other "onyms" not included in this definition include toponyms or words named after a geographic location (e.g. St. Louis encephalitis), ethnic group or ethnonym (e.g. Japanese encephalitis), and demonyms, or words named after residents or natives of a particular place or location (e.g. German measles). The major problem with the latter is that they fail to differentiate ethnic place or origin from residency or citizenship [7]

Those who call for the disbarment of their use cite a number of limitations (Table I) [8, 9]. Despite these drawbacks, it has been argued that medical eponyms impart an appreciation for the keen insights applied by physicians and scientists in recognizing and/or applying a particular finding [10].

Many eponyms remain firmly entrenched within medical terminology and are unlikely to disappear (e.g. Babinski sign, McBurney point). In physical diagnosis, medical eponyms reinforce the importance of applying the fundamental aspects of the examination in diagnosis, enhance our understanding about symptoms, syndromes, and diagnosis, improve clinical reasoning skills, and promote understanding of the pathophysiology 
Table I. Arguments supporting and opposing the use of eponyms [8-10]

\begin{tabular}{|c|}
\hline Supporting \\
\hline May provide, in some cases, a brief and succinct method of recall and communication \\
\hline Honor a person's contribution to medicine \\
\hline Imparts an appreciation for insights applied by physicians in recognizing, eliciting, discovering or describing a phenomenon \\
\hline Provide an opportunity to learn about historical content and perspective regarding the discovery \\
\hline Embody the tradition and art of medicine \\
\hline Opposing \\
\hline $\begin{array}{l}\text { Original paper may not be accessible since it was written in another language, monograph, or presented at a conference, } \\
\text { journal not available, or lack of awareness of publication (e.g. Branham sign - Harris Miller Branham published in } 1890 \text { but } \\
\text { Carl Nicoladoni published in } 1875 \text { and James Adolf Israel in } 1877 \text { a similar phenomenon) }\end{array}$ \\
\hline $\begin{array}{l}\text { The description may be a departure from that which had been accurately translated from the native to another language } \\
\text { (e.g. Trousseau syndrome) }\end{array}$ \\
\hline $\begin{array}{l}\text { Often honors only one person although there may be significant contributions from others including co-authors in the } \\
\text { discovery (e.g. Hill sign authored by Hill, Flack and Holtzman) }\end{array}$ \\
\hline $\begin{array}{l}\text { May honor the first, senior, or one who more thoroughly described the finding rather than the original author (e.g. de Winter } \\
\text { sign vs. William Dressler who originally described the finding, Wellens sign published by de Winter, Verouden, Wellens, } \\
\text { and Wilde) }\end{array}$ \\
\hline $\begin{array}{l}\text { The name may be misspelled (e.g. Graham Steell), middle name used (e.g. Albert Boyce Barrow for Boyce sign), the same } \\
\text { physician might have multiple discoveries eponymously attributed (e.g. Jean-Martin Charcot), or multiple use of the same } \\
\text { surname can refer to different individuals in the same (e.g. William Henry Broadbent, Walter Broadbent, John Francis } \\
\text { Broadbent) or different families (e.g. Chevalier Jackson, James Jackson, John Hughling Jackson) }\end{array}$ \\
\hline $\begin{array}{l}\text { Different names may be used in different countries for the same condition (e.g. Sjögren syndrome vs. Gougerot-Sjögren } \\
\text { syndrome in France) }\end{array}$ \\
\hline $\begin{array}{l}\text { Particularly in regards to medical eponymic signs, most have not been well studied and validated for scientific accuracy. } \\
\text { For the few that have been studied, there are a number of problems with study design and methodology limiting the ability to } \\
\text { draw meaningful conclusions such as selection bias, inconsistency in case definitions and reference standards, sample } \\
\text { size and range of disease severities (e.g. Corrigan, Duroziez signs) }\end{array}$ \\
\hline
\end{tabular}

of disease. They also provide opportunities for further investigation in order to determine their accuracy and validity in clinical practice. Therefore, it is important to avoid premature closure of abandoning eponyms until they have been appropriately studied and vetted through an evidence-based approach.

The authors declare no conflict of interest.

\section{References}

1. Nieradko-Iwanicka B. National eponyms in medicine. Reumatologia 2020; 58: 56-57, DOI: 10.5114/reum.2020.93175.

2. [No author listed]. Classification and nomenclature of morphological defects. Lancet 1975; 305: 513, DOI: 10.1016/ s0140-6736(75)92847-0.

3. Fukuda K, Wang R, Vallat B. Naming diseases: first do no harm. Science 2015; 348: 643, DOI: 10.1126/science.348.6235.643.

4. [No author listed]. WHO best practices for naming of new human infectious diseases. May 2015. Retrieved: https://www. who.int/topics/infectious diseases/naming-new-diseases/ en/ (accessed: April 29, 2020).
5. Orbey E. Trump's "Chinese virus" and what's at stake in the Coronavirus's name. The New Yorker. March 25, 2020. Retrieved: https://www.newyorker.com/culture/cultural-comment/whats-at-stake-in-a-viruss-name (accessed: April 30, 2020).

6. Strous RD, Edelman MC. Eponyms and the Nazi era: time to remember and time for change. Isr Med Assoc J 2007; 9: 207 214, PMID: 17402342.

7. Rosenberg M. Demonyms: the names of nationalities. ThoughtCo, Feb. 11, 2020. Retrieved: thoughtco.com/the-names-of-nationalities-4088817 (accessed: April 30, 2020).

8. Aronson JK. Medical eponyms: taxonomies, natural history, and the evidence. BMJ 2014; 349: g7586, DOI: 10.1136/bmj. g7586.

9. Woywodt A, Matteson E. Should eponyms be abandoned? Yes. BMJ 2007; 335: 424, DOI: 10.1136/bmj.39308.342639.AD.

10. Whitworth JA. Should eponyms be abandoned? No. BMJ 2007; 335: 425, DOI: 10.1136/bmj.39308.380567.AD. 